\title{
Motivating Teachers to Use the School
}

\section{Library}

\section{Josip Rihtarić}

Josip.Rihtaric@skole.hr

$2^{\text {nd }}$ Elementary School in Varaždin, Croatia.

Keywords: motivation for using school library, teachers, most important users, round table, reading list, coffee tabs

\section{Abstract}

The participants will be introduced with several procedures a school librarian can motivate teachers to use the school library. Some of the procedures can be applied globally in all school libraries, while others are specific to Croatia, or countries with a similar education system.

Teachers are not the most numerous, but they are the most important users of school library. When teachers support the work of school librarian, he or she can fully accomplish his or her mission. If the support from teachers is missing, school librarian can employ different strategies to motivate students to use the school library, but only with a limited success. In order to motivate teachers to use the school library and to encourage the cooperation between them, the school librarian and the teachers, the librarian can initiate several activities, some of which are to be presented. The inspiration for these activities was James Henri's presentation at the IASL conference in Italy in 2009.

\section{Annotation in the Library Catalogue}

Once, when I was able to acquire an unusually large number of books, I used this occasion to buy a couple of books for each literary fields, for all school subjects. I chose 2 books for each teacher based on the subject he or she teaches and their personal preferences. I approached each of them personally and asked them to skim through the books in the following 2-3 months, and if they wanted to they were, of course, more than welcome to read the books. I asked them to answer a couple of questions, and these answers would be used as the annotation in the library catalogue, which should be useful to other teachers and students. It is very useful when the annotation is made by the experts of that area. In total I shared 102 books to 51 teachers and professional teaching assistants. The answers they gave to the questions are now annotations in the school library catalogue. These were the questions I gave to my colleagues:

Please skim through (or read) these two books and help me with your evaluation!

1. Could this book or any part of this book be used in teaching as a teaching tool or source? How?

a) by copying a couple of pages as a work material for students

b) by reading parts of the books to the students

c) by referring students to the book when writing homework, school work, presentation or a poster 
d) some other way:

2. Could this book or any part of this book be used for some teaching subject, extracurricular activity, interdisciplinary topic (civic education, health education, education, etc.), project, project days, integrating-correlating classes that combine several subjects, for professional training, for teachers' personal growth...? Please explain your answer.

3.To whom will you recommend this book? To a teacher of a particular subject or one-teacher education (elementary school) teacher, to the principle of a professional teaching assistant, to your friends, wife/husband, children, elementary school students, students of $5^{\text {th }}$ and $6^{\text {th }}$ grade, students of $7^{\text {th }}$ and $8^{\text {th }}$ grade, ...? Please explain your answer.

4. Do you think that this book must be in the reading room collection so that it can always be available to everyone or would it be better if it was to be borrowed so that library users can take it and read it at home?

5. Do you think that another copy of this book should be bought for teachers as a reference book (the books that teachers used as reference books are bought from another source, they are not registered as school library books, instead they are permanently at a certain teacher)? Would you, in this case, consistently (several times in a school year) use this book as a reference book for your classes?

6. What other books should be bought for the school library, either for students or teachers to borrow them or for the reading room collection - please write down the title and the author (if you need a reference book that will be available to you all the time, please contact the principle; such books are not registered in the school library and are not bought as a part of school library fund).

7. How would you grade from 1 to 5 this book?

Being interesting (when you start reading you cannot stop. ...)

Being useful (interesting and useful pieces of information which are good to know)

Being applicable (in teaching, for teachers, for students, ...)

General grade, how much did you like the book in general?

Does the school library need more similar books (of similar topic and content)? Yes-No.

P.S. you can also write a broader annotation or book presentation which will then be written in the library catalogue.

\section{Teachers' Basket}

Teachers rarely come to school library on their own initiative, but they do come to the teacher's room every day, which is the perfect location to place a teacher's basket - a basket filled with books for the teachers. Teacher's basket is something similar to a class library. The basket includes a notebook with the names of all teachers and professional teaching assistant to keep track of what books they are reading. Each month I chose ten interesting books and at the beginning of each month I changed the contents of the basked. The chosen books were supposed to serve as a reminder that there are many similar books in the school library. 


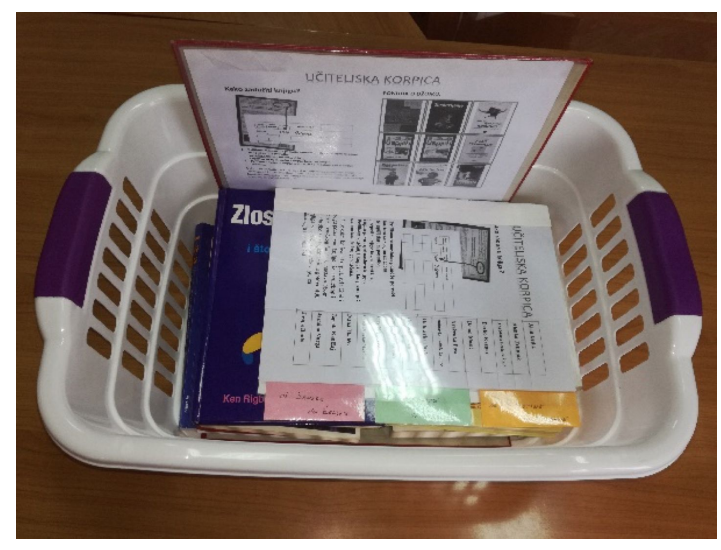

Figure 1. Teachers' Basket (own photo)

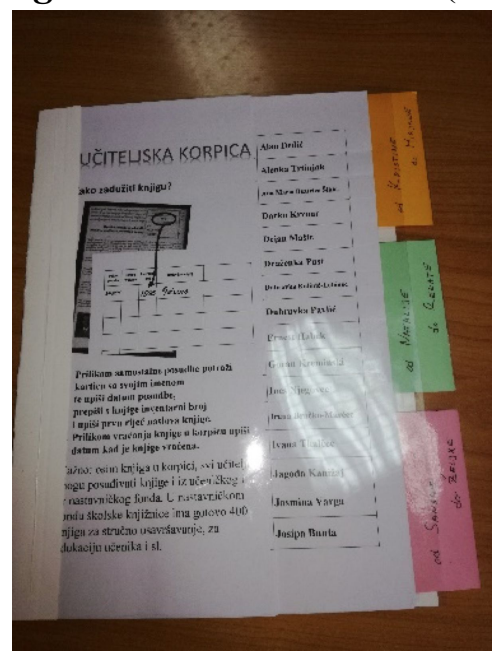

Figure 2. Teachers' Basket - Notebook cover with instruction (own photo)

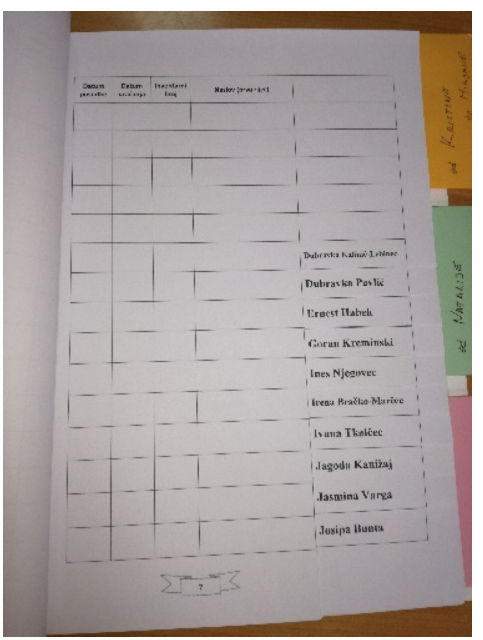

Figure 3. Teachers' Basket - Notebook page 7 (own photo) 


\section{Around the Round Table}

Cooperation with teachers is possible only if we have good relations with them, and in order to establish good relationships, it is necessary to spend time together, continually and actively, for at least six months. Such intensive meetings are most easily accomplished through small target groups. That is why the past several years I spend time with my colleagues in small group meetings with the purpose of self-development education.

In the school year 2016/2017 I organized two rounds of 6 round tables with the colleagues from my school. I adjusted the times to the classes in our school so I simultaneously held the same education with three groups. The groups were formed based on the teachers' timetables: when they had a period without teaching (but had classes before and after), in this free period we would meet as a small group and go over the materials. In particular, it was $4^{\text {th }}$ period on Wednesday and $3^{\text {rd }}$ and $4^{\text {th }}$ period on Friday. The colleagues were very content with the round tables and proposed that we continue this kind of meetings and work on personal growth. The two following school years I prepared new materials, more colleagues joined and we formed more groups and the education was extended to the entire school year.

\section{Podsjetnik na druženje u školskoj knjižnici uz kavu ili čaj!}

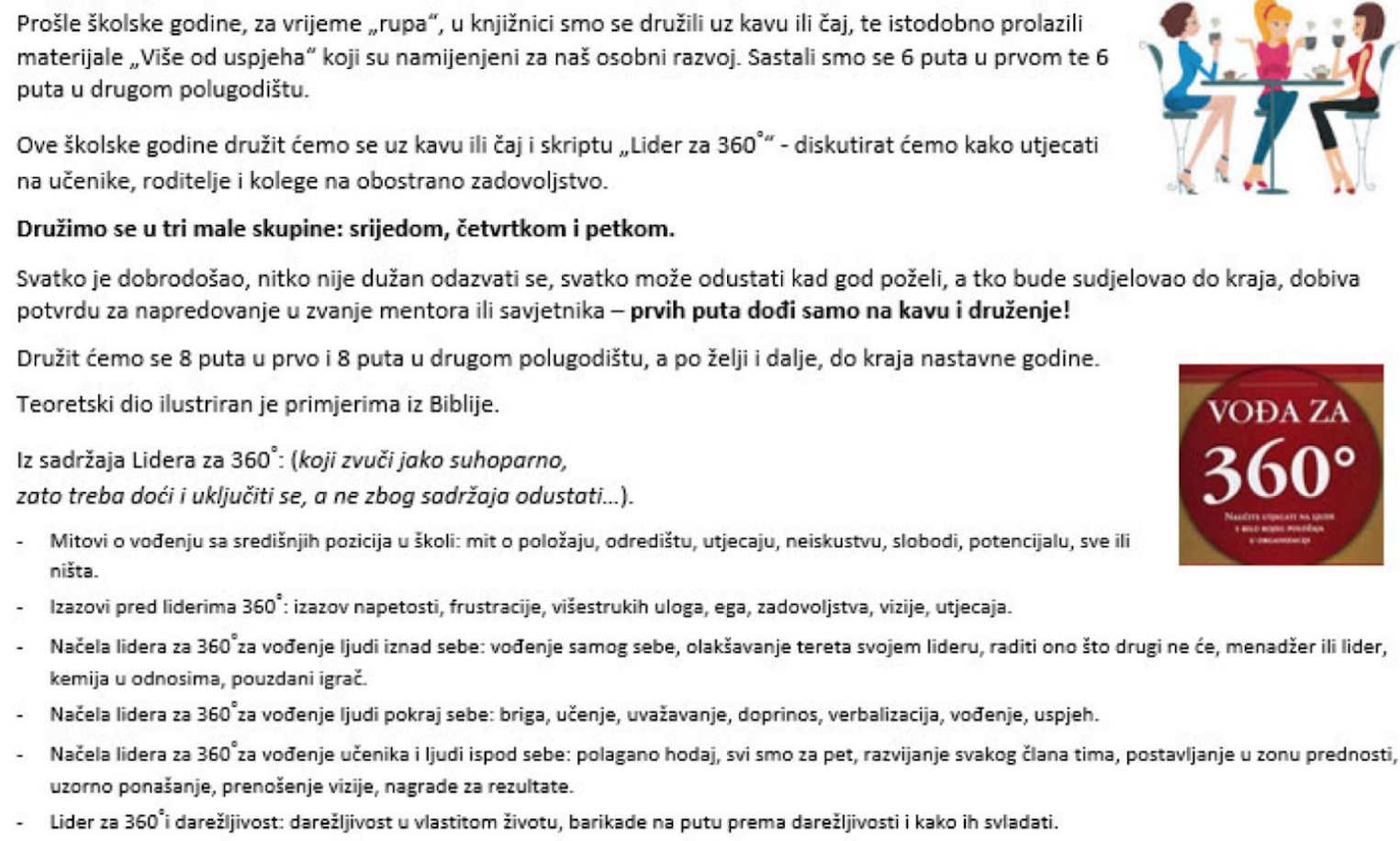

- Mitovi o vođenju sa središnjih pozicija u školi: mit o položaju, odredištu, utjecaju, neiskustvu, slobodi, potencijalu, sve ili ništa.

Figure 4. Announcement, invitation and reminder for the Round Table 2017 (own photo)

The primary goal of these meetings was to empower my colleagues in their personal growth and development. Unlike those employed in the business sector, public educators usually do not have the possibility to advance in their jobs nor can they get substantial salary raise: these usually stay constant throughout our careers. It is not rare that our colleagues retire frustrated and displeased, instead of finishing the work-period of life with the feeling of content and fulfillment. As a consequence, some turn 
to the saying "you cannot pay me as little as I can earn" (which then, in turn, results in discontent), while others try to build their own intrinsic motivation in order to keep doing what they like with joy.

I completed an education on leadership where we were given the materials and instructions for working on personal growth. I assessed the materials to be particularly interesting for us working in education, consequently, offered the colleagues in my school such personal growth trainings as I participated in. Given that this is education, they can receive a confirmation of participation from Education and Teacher Training Agency, which they can then use in their personal record for promotion in their title.

The round tables, simply said, have the following structure. First each of the participants reads one paragraph in the given text about personal development. While reading, everyone underlines the most interesting parts. Then participants (and the group leader) share the parts they underlined and explain why they found them particularly interesting. Once everyone has shared their underlined part, everyone fills the questionnaire and then summarizes others what has written. The questionnaires are written in such way that participants have to reflect on the written text and there is always a question that requires the participant to give himself or herself a task that has to be accomplished during the following week. At the beginning of the next round table, each participants shares with other the experience and how successful he or she was in accomplishing the task. This task usually motivates us to reread and affirm the materials that were read during the round table.

The most valuable element of these round tables is that I was able to see how each of my colleague relates to different life values from the materials. During these meetings the participants discover the qualities and talents that each of us has and in such way we can grow stronger and braver, we can support and enrich each other and ourselves. The materials for these round tables are written based on the books by John C. Maxwell.

Given that I am school librarian, and one of my areas of work is information literacy education, which is also my personal interest, the secondary goal of this education was to implicitly apply the methods of work with information and practice different skills of information reading. 
Figure 5. Announcement, invitation and reminder for the Round Table 2019 (own photo)

\section{Lectures and workshops for the teachers on the faculty meetings and in the school library}

Every few years on the faculty meetings in my school I hold a presentation or a workshop for all teachers on a topic related to the school library with the purpose of acquainting the teachers with the benefits in their job they can draw from cooperating with the school librarian.

Four times each school year I organize, after the classes, in the afternoon in the school reading room a video-projection of educational material that encompasses cooperation with school library. This is followed by questions and reflection tasks as well as discussion.

\section{Reading Lists}

When it comes to the reading lists, many school librarians in the majority of schools in Croatia are already in a conflict. The general view is that the more books are borrowed in a school year, the better the school library and the librarian. The librarian has to do everything in his or her power to make the users content, and the users are not content if in the library there are no books they want to borrow. On the one hand, the school librarian is expected to ensure enough copies of each book from the reading list. On the other hand, school libraries usually do not have enough space to hold so many books from the reading lists so that all of the students from the same grade can read these books at the same time, and also, there is no systematic solution for permanent financing of library resources. 
One of the solutions to this problem is that not all of the students read a book at the same time, but to have each class read the same books at different times throughout the school year. However, Croatian language teachers are usually not content with this idea as they would prefer that all of the students (students from all the classes of the same grade) read the same books at the same time.

It is left to the librarian to find a way to communicate this problem to the teachers and convince them not to read the same book at the same time with all the classes of the same grade but to keep motivating their students to use the school library (and not the city library).

Communication between the school librarian and the teachers of Croatian language is crucial. Teachers see the situation from their own perspective and often neglect the fact that the school library does not have enough copies to suffice for the entire grade, but only for one class. Poor communication can result in teachers sabotaging school library in different ways. In addition, a straightforward consequence of teachers insisting on students from all classes reading the same books at the same time is that not all students will be able to borrow books from the school library. The problem is twofold as such teachers' decision will make it impossible for all of the students to receive the same treatment in school and the success and well-functioning of the library will be seen as worsened. In such case, students are forced to borrow books from other libraries, such as city library (where they have to pay the membership), and there will be less borrowing in the school library with the conclusion that the school library is not good enough. In addition, the librarian will be seen as not good enough at his or her job because of failing at providing enough books for all of the students, thus making the users of the library discontent.

In order to avoid such situations and to make it possible for all students to borrow all of the books from the reading list, for years I have been taking certain measures. At the end of a school year, I give all of the teachers of Croatian language a list of all of the reading list books with the number of copies that the school library has. For each class of each grade I suggest a reading list schedule - such that there are no overlaps. Once that the teachers confirm the reading list schedule, for each class I create a clear list of the books with the photograph of the book cover, short description of the book, indication of estimated reading time, and for each student I create a shortened reading list that students can put into their notebook or somewhere they find it useful. During the first or second school week, I have an introductory class into reading list books with all of the students of $5^{\text {th }}-8^{\text {th }}$ grade. For the students of $6^{\text {th }}$ grade this is in the form of "Book casting", and for the students of $7^{\text {th }}$ and $8^{\text {th }}$ grades I prepare a Kahoot quiz. Here students have the opportunity to look at all the books they will be reading during this school year, and at the end of the class they receive the reading list schedule. For the classrooms in which Croatian language classes are held I make a poster with all of the titles from the reading list and the basic information about the school library, with the goal of reminding the students to read and borrow books from the school library. At the end of school year, I prepare another Kahoot quiz, this time with the questions about the books from the reading list - and for the winners of the quizzes I provide symbolic prizes. 


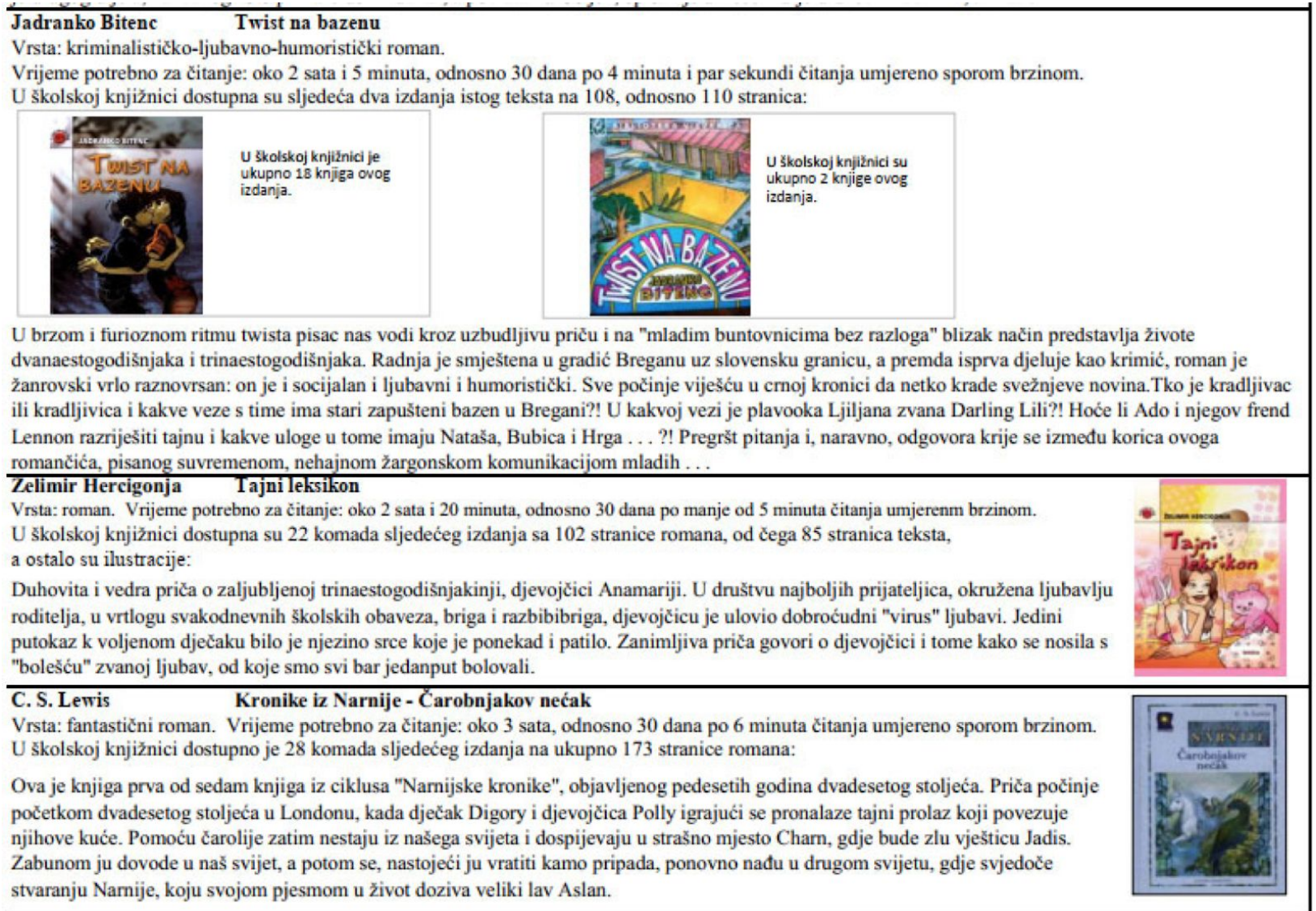

Figure 6. Part of the Poster for the class 6.d (own photo)

\section{The List of New Books}

Throughout the school year there are relatively few new books, once a year I create a list of new books and deliver it to the teachers' room so that the teachers who usually do not come to the school library have the chance to see what is new.

\section{Bibliography}

For each teacher I create, print and deliver a bibliography of books for his or her teaching area, as well as a bibliography of pedagogical and didactic books that are useful for all teachers. It may seem that printing bibliographies on paper is nowadays superfluous, impractical, and expensive, the results are surprisingly positive. Having a printed bibliography at hand is practical as teachers can read through it, mark it and highlight it and it has proved to be much easier to access than searching for it on laptop or email.

\section{Exhibitions, encounters with writers, introduction to statistics, quizzes, etc.}

In order to keep continuously reminding teachers about the possibility of using the school library, I organize activities that usually are associated with school librarians, such as exhibitions, encounters with writers, creation and distribution of materials such as statistics of borrowings.

Using "library window" that is located in a hallway in the middle of school, I organize different games with prizes for both students and teachers. There is a question to which teachers have to answer via social networks and come to claim their prize in the school library until a certain day. This gives the librarian the 
opportunity to talk to a teacher with whom he or she might have not communicated in a while, and that teacher will, by sharing this experience of the game, motivate other teachers to use the school library, and remind them that there are different activities for them in the school library.

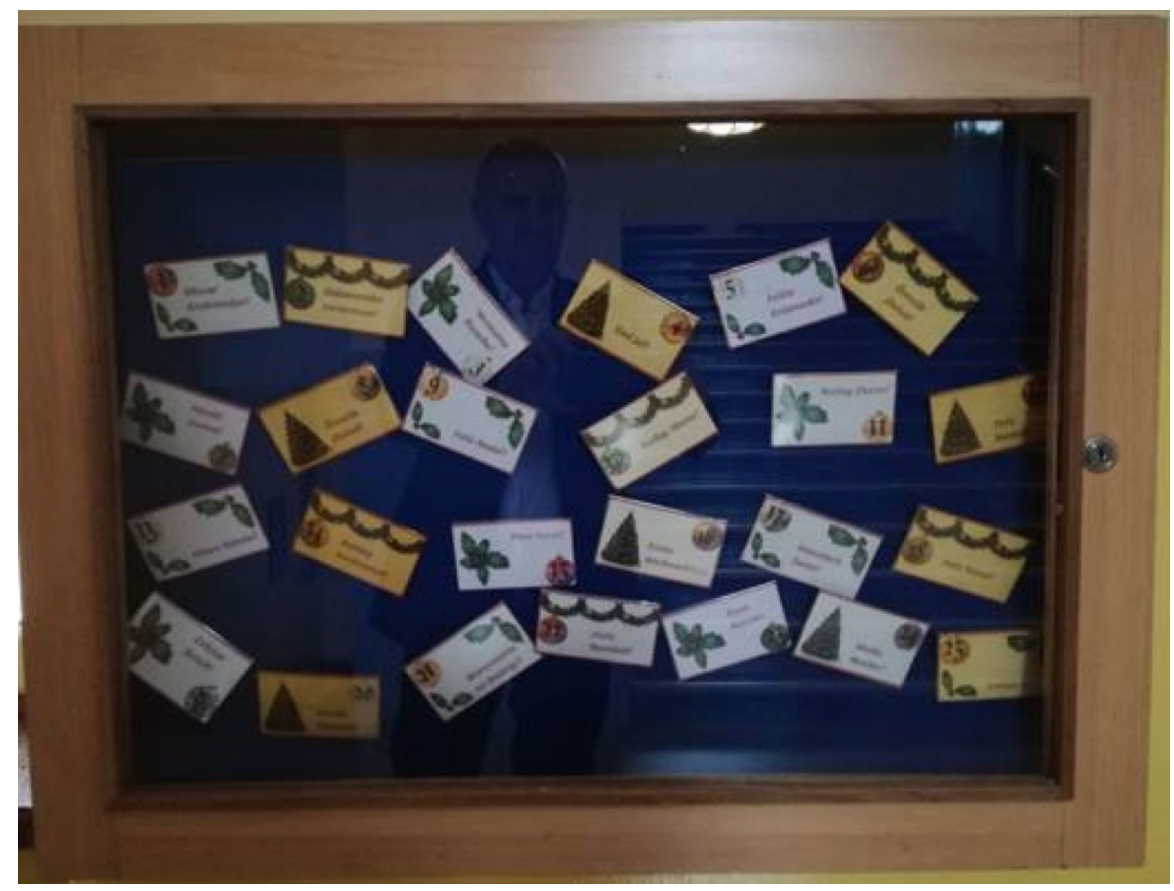

Figure 7. Advent Calendar - Game with Prize in the Library Window (own photo)

\section{Coffee Tabs}

Croatians are coffee lovers. Lately on the market there have been different coffee machines with coffee tabs, but each machine has different tabs so it is difficult to taste and try all of the coffee machines. I purchased on of these coffee machines and gave tabs to the colleagues in my school. The coffee machine is in the library so in order to have coffee they have to come to library, which gives us yet another opportunity to talk and organize some cooperation and mutual work, such as shared class or to invite them to motivate students to use the school library.

\section{Conclusion}

Teachers are, alongside with the principle, crucial people for deciding how much students will use the school library. If teachers do not motivate students to use the school library, the impact of the school librarian is very limited. The most effective way to get the teachers to motivate students to use the school library would be laws and rulings. If these, obviously, do not exist, it is all left to the willingness of the teachers. This automatically gives the school librarian the task to persuade teachers to use the school library and to create different strategies and activities to motivate teachers to use the school library, to create an environment in which using the school library will be, for teachers, at the same time useful and pleasant. 


\section{REFERENCES}

Dickinson, G. \& Repman, J. (2015). School Library Management. Columbus, OH: Linworth Books.

Doll, C. A. (2005). Collaboration and the School Library Media Specialist. Lanham, MD: The Scarecrow Press.

Keeling, J. (2017). Standards-Based Lesson Plans for the Busy Elementary School Librarian. Santa Barbara, CA: Libraries Unlimited.

Kuhlthau, C. C., \& Maniotes, L. K., \& Caspari, A. K. (2015). Guided Inquiry : Learning in the 21st Century. Santa Barbara, CA: Libraries Unlimited.

Morris, B. J. (2004). Administering the School Library Media Center. Santa Barbara, CA: Libraries Unlimited.

Stein, B. L., \& Brown, R. W. (2002). Running a School Library Media Center: A How-To-Do-It Manual for Librarians (How to Do It Manuals for Librarians). Chicago, IL: Neal-Schuman Publishers.

\section{Biographical Note}

Josip Rihtarić has been School librarian since 1997 in the $2^{\text {nd }}$ Elementary School in Varaždin, Croatia. He is one of the founders and secretary in two mandates of Croatian Network of School Librarian. He has been member of HUŠK since the establishment of HUŠK.

He was the chairperson of the county professional assembly 2 mandates. He published several articles, presented and led workshops on professional national assemblies and numerous county assemblies. The Education and Teacher Training Agency of Croatia one time promoted him to the professional associate mentor and twice to the status of professional associate counselor. 